\title{
The Effect of Snake Venom Anti Thrombus Enzyme on Deep Vein Thrombosis
}

Sjukri Karim

\begin{abstract}
Abstrak
Seorang laki-laki usia 40 tahun yang sebelumnya sehat mendapat deep vein thrombosis pada kaki kanannya yang telah berlangsung dua minggu. Diagnosis ini berdasarkan pemeriksaan fisik dan dipastikan oleh hasil pemeriksaan Doppler dan flebografi. Faktor predisposisi pada pasien ini adalah obesitas, pekerjaan yang banyak duduk diam dan hiperfibrinogenemia. Pemberian heparin sesuai protokol yaitu dosis awal 5000 unit (bolus) yang dilanjutkan dengan pemberian infus dalain dosis mempertahankan nilai "activated partial thromboplastin time" 1.5-2 kali diatas kontrol selama dua minggu tidak menunjukan perubahan klinis. Pengobatan dengan snake venom anti thrombus enzyme memberi hasil yang memuaskan tanpa efek samping.
\end{abstract}

\begin{abstract}
A 49-year-old previously healthy gentleman suffered from deep vein thrombosis on his right leg for two weeks. The diagnosis was based on physical findings and confirmed by doppler and phlebography examinations. The predisposing factors were obesity, sedentary profession and hyperfibrinogenemia. Two weeks administration of heparin with initial dose of 5000 unit and followed by 1000 unit/hour for 2 weeks to maintain activated partial thromboplastin time at 1.5-2 times control level had no clinical effect. The snake venom ant thrombus enzyme (SVATE) treatment was then used and achieved a satisfactory result without any adverse effects.
\end{abstract}

Keywords : Deep Vein Thrombosis, Snake Venom Anti Thrombus Enzyme.

\section{INTRODUCTION}

The purified Snake Venom Anti Thrombotic Enzyme3 (SVATE-3) is a new type of thrombolytic and anticoagulative agent developed in China. It has been reported that SVATE-3 effective in treating various angio-thrombotic diseases such as: cerebral thrombosis, myocardial infarction, and unstable angina pectoris without any remarkable side effects. ${ }^{1}$

We report a first case of Deep Vein Thrombosis (DVT) which has been successfully treated by SVATE-3, while heparin failed to improve symptom.

A 49-year-old gentlemen was admitted to the hospital with a 2-week history of a swollen leg. It started with slight swelling on his foot: three days later, the swelling gradually developed to the knee and then to the thigh. He could not walk properly with a painful and numbness sensation in his right leg.

Before the occuring of the swollen foot, he was in a good stage of health. He did not have any injury, fever or lumping on the groin. He did not have a recent operation. He did not have heart disease, diabetes mellitus or hypercholesterolaemia, but he had hypertension. He did not smoke and he ate normally. His body weight was stable before he had the disease. He worked as a clerk for more than 20 years.

\section{PHYSICAL EXAMINATION}

He looked fat and healthy. Blood pressure was $120 / 80$ $\mathrm{mmHg}$, pulse rate $75 \mathrm{x} /$ minute, respiratory rate $16 \mathrm{x} /$ minute, body temperature $36.5^{\circ} \mathrm{C}$. Normal first and second heart sounds; no murmur was found. Normal breath sound; no rhonchi or wheezing were heard. Liver and spleen were non-palpable, no ascites was detected. There were no abnormalities found in the upper extremity and the left leg. The right leg however looked swollen, cyanotic and hyperpigmentation of the skin. It was still warm, and the femoral and pedal 
pulses were still obtainable with a positive Homan's sign, Payr sign, Lowenberg sign and Meyer sign.

Electrocardiogram and chest $\mathrm{X}$-ray were within normal limit. Blood examination showed the following result : $\mathrm{Hb} 13.8 \mathrm{~g} \%$, W.B.C. $9.900 / \mu \mathrm{l}$, Blood Sedimentation Rate $55 \mathrm{~mm} /$ hour, thrombocytes $272.000 / \mu 1$. clotting time 6.5 minute, bleeding time 2.0 minute, fibrinogen $492 \mu \mathrm{g} / \mathrm{dl}$, AT-III $113 \%$, Filariasis $(-)$, liver function test was within normal limit. Stool and urine examination revealed no abnormalities.

Doppler sonography showed a reduction of venous flow and was not affected by respiration, which indicated a deep vein thrombosis (Figure 1). Phlebography showed thrombus in the $\mathrm{V}$. tibialis anterior, $\mathrm{V}$. Crurialis profunda and $1 / 3$ distal of the $\mathrm{V}$. femoralis.

Based on the history, symptom and sign, physical examinations, doppler and phlebography results, the diagnosis of deep vein thrombosis (DVT) was confirmed.

\section{MANAGEMENT}

The patient was placed on bed rest with the right leg elevated approximately 30 degree. Heparin was started with 5.000 unit (I.V. bolus) followed by 1.000 unit/hour, and then the dose was increased gradually by maintaining activated partial thromboplastin time (APTT) at 1.5 to 2 times control level.

After receiving a 14-day course of heparin, there was no significant improvement found (Figure 2). The treatment was then changed to Snake Venom Anti Thrombus Enzyme-3 (SVATE-3).

SVATE- 3 was given as recommended, that was 4 ampules disolved in $10 \mathrm{ml}$ of normal saline and administered intravenously directly; another 4 ampules disolved in $250 \mathrm{ml}$ of normal saline and administered intravenously with the rate of 45 drops/minute.

A 14-day course of SVATE-3 treatment achieved satisfactory results subjectively and objectively; such as the decreasing of pain and numbness sensation, improvement in moving, increasing blood flow (Figure 1) and reduction of the sweeling on the right leg (Figure 2).

\section{DISCUSSION}

Deep vein thrombosis (DVT) in the lower extremity is the main source for pulmonary embolism; it therefore poses as a challenging and potentially life saving investigation.

Hemostatic abnormalities such as deficiency of antithrombin III, protein $\mathrm{C}$ and protein $\mathrm{S}$, increase in fibrinogen, disorder of plasminogen etc, ${ }^{2}$ and clinical risk factors including obesity, cancer, bed-rest, varicose vein, stasis, estrogen treatment ${ }^{3}$ may promote DVT. This is in accord with our patient, who is obese, has a sedentary profession and has increased fibrinogen.

Fibrinolytic and antithrombotic therapy are still the mainstay of treatment for DVT. ${ }^{4}$ In this case, streptokinase, urokinase, tissue plasminogen activator (tPA), or ultra-high-streptokinase therapy were not given because it has been reported that these agents were prone to lyse fresh platelet-fibrin hemostatic plug, ${ }^{5}$ while this patient had a 2 -week episode. Heparin was given to prevent further clot formation. However, there was no sign of clinical improvement as a clot lysis by normal hemostatic system ${ }^{6}$ after 14 days of heparin therapy. The reason of this was unclear; one possibility was that the infusion rate of heparin with drips may be influenced by the patient movement causing a fluctuation of APTT level (Note: the APTT level was taken 12-hourly). Therefore, there might be a continous apposition of new thrombi to halt the recanalisation process. We then decided to start with SVATE treatment.

It has been shown that SVATE-3 treat angiothrombotic disease with a $90 \%$ success rate. ${ }^{1}$ It is a multifunctional enzymic preparation with anticoagulating and thrombolitic effects. Various studies showed that the thrombolitic effect of SVATE is superior to urokinase or streptokinase on white thrombi and old detached thrombi. ${ }^{\top}$ One of the mechanism for the thrombolytic effects of SVATE-3 may also be associated with the inhibition of the platelet $\mathrm{GP}_{\mathrm{IIb} / \mathrm{III}}$ receptor. $^{8}$

The effect of SVATE in this patient judged from the releaving symptoms and reducing the swelling of the leg was surprising (Figure 2). There were no side effects found during SVATE treatment. This finding supports the previous studies of the thrombolytic efficacy and savety of SVATE.

However, since it has only been used in one case, more study is needed for establishing the effectiveness of SVATE in the treatment of DVT.

Note :

Besides the patient reported above, there were 3 other patients who were successfully treated by SVATE-3. However, one patient who was recently treated with different batch number of SVATE-3 showed no improvement of symptom, nor increased of fibrinogen degradation product.

\section{REFERENCES}

1. Hao WX. The comparative study for the anticoagulative effects of antithrombus enzymes-1,2,3 on the animal. In: 

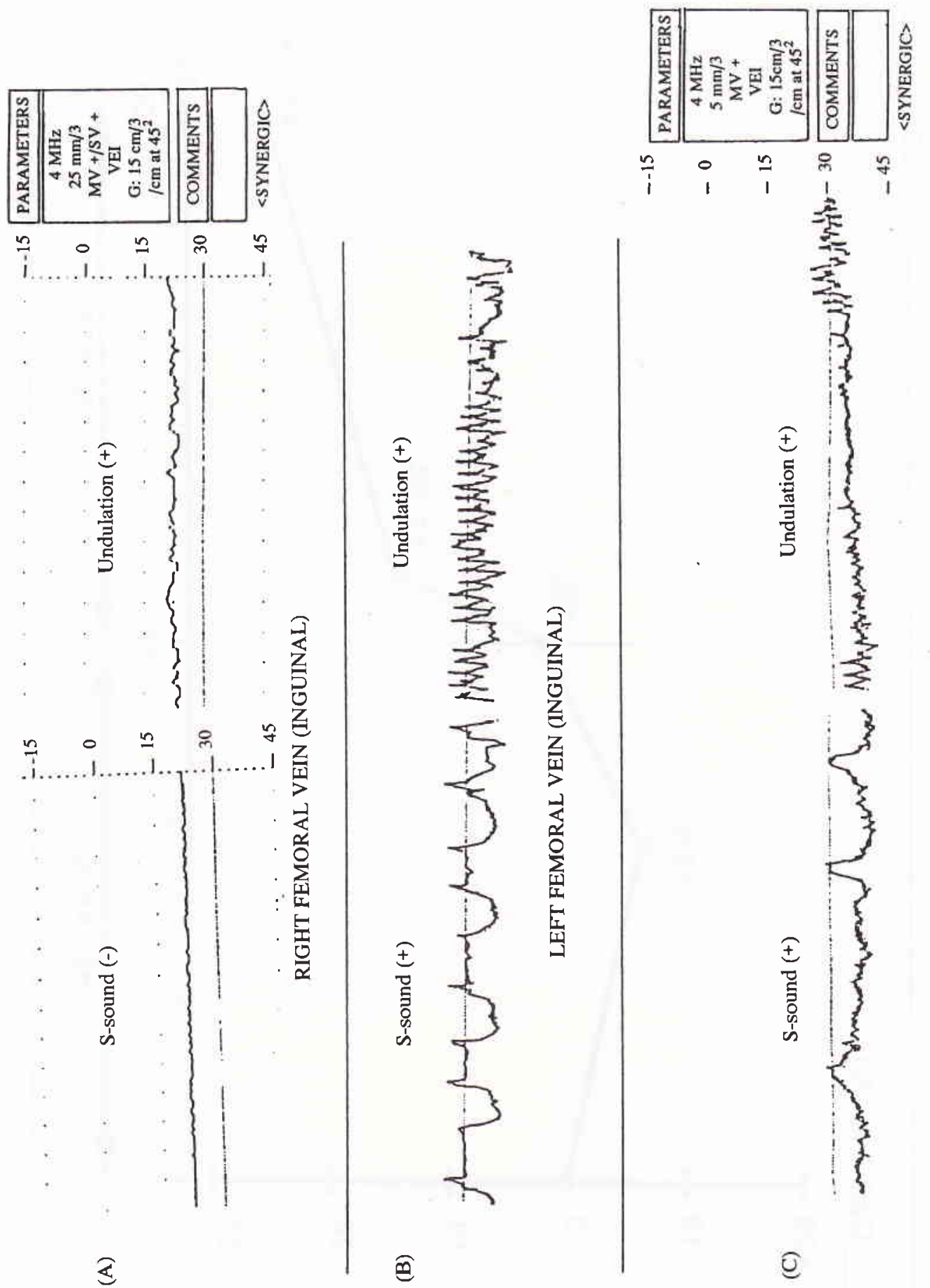

是

Figure 1.

\section{Doppler flow signal on :}

A. Right femoral vein (inguinal) when the patient first arrived. No blood flow was recorded both in inspiration and undulation. Compared to

B. Left femoral vein with normal blood flow.

C. Right femoral vein after Snake Venom Thrombus Enzyme (SVATE) treatment; the blood flow was recorded. 


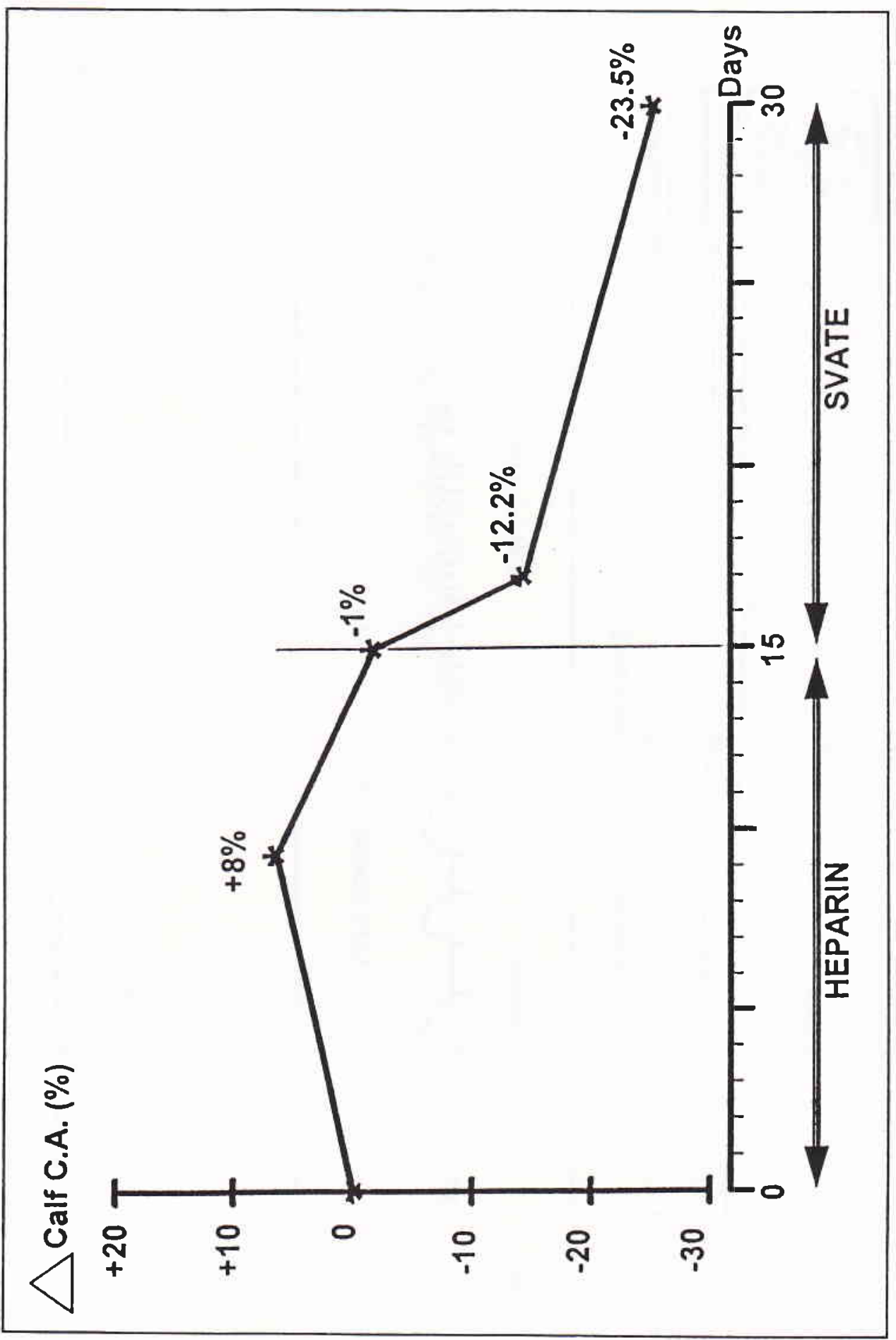

Figure 2.

Right calf circumference area (CCA) changes during heparin (15 days) and snake venom anti thrombus enzyme (SVATE) (15 days) treatment.

There were no significant changes in CCA during heparin treatment. However, the CCA dropped significantly after two days 
The compilation of achievement in scientific research of refined antithrombus enzyme-3 (SVATE-3). China Med Univ 1991: 106-12.

2. Clagett GP, Anderson FA, Levine MN, Salzman EW, Wheeler HB. Prevention of venous thromboembolism. Chest 1992; 102: 391S-407S.

3. Anderson FA, Wheeler HB. Physician practices in the management of venous thromboembolism: A communitywide survey. J Vasc Surg 1992: 16: 707-14.

4. Hyers TM, Hull RD, Weg JG. Antithrombotic therapy for venous thromboembolic disease. Chest 1992; 102: 408S$25 \mathrm{~S}$.

5. Santosa F, Matthias FX. Ultra Hoch Streptokinase Therapie (UHSK) bei DVT nichtpublizierte befunde, Medizinishe Intensivstation- Klinikum der Justus liebig Universitat Giessen 1989.
6. Handin RI, Loscalzo J. Hemostasis, thrombosis, fibrinolysis, and cardiovascular disease. In: Heart Disease, A Textbook of Cardiovascular Medicine. Ed. E. Braunwald. Third edition 1988; chapter 56: 1758-81.

7. Pan WM, Chang JF, Li L, Yang ZM, Liu YB. Experimental research of the thrombolytic effect of snake venom anti thrombus enzyme on the coronary thrombus in dogs. In: The compilation of achievement in scientific research of refined antithrombus enzyme-3 (SVATE-3). China Med Univ 1991: 10-42.

8. Yasuda T, Gold HK, Leinbach RC et al. Kistrin, a polypeptide platelet GP IIb/IIIa receptor antagonist, enhances and sustains coronary arterial thrombolysis with recombinant tissue type plasminogen activator in a canine preparation. Circulation 1991; 83: 1038-47. 